\title{
STRATEGIC INTERNAL COMMUNICATION: ANALYSIS OF THE PRACTICE OF REGIONAL HIGER EDUCATIONAL INSTITUTIONS OF LATVIA
}

\author{
Ieva Zaumane \\ Vidzeme University of Applied Sciences, Latvia
}

\begin{abstract}
In the organization's strategic management, internal communication is one of the main components enabling the strategic management process to be carried out. Its role is important in both the planning and implementation of the strategy. Still, in practice, the internal communication's potential remains untapped, resulting in the pursuit of organizations' strategic objectives. In developing the doctoral thesis, the author has an interest in investigating not only businesses, but also higher education institutions (HEIs), as they are similar organizations to other sectoral institutions, and their processes must be similar. The purpose of this study is to analyse who currently manages the internal communication function of four Latvian regional universities and to what extent the internal communication can be considered strategic. The study reviews international literature on the strategic management of organizations and the strategic management of internal communication. It uses a combined research strategy involving questionnaires and semi-structured interviews with respondents indicating that their university has developed an internal communication strategy.

The results show that the internal communication management practices of universities differ since some universities do not clearly define the purpose of internal communication, strategies, and plans, as well as those which merely indicate the existence of internal communication management practices. In all four universities, specialists carry out internal communication in the field of marketing, communication, or human resources management who demonstrate that private business practices are being applied - implementing internal communication in fragmented ways without acknowledging it as a management's function.

The research participants have indicated that internal communication should be managed by the administrative vice-rector. Since the analysed articles show that the employee responsible for the internal communication function should be part of the decision-making process, more in-depth research should be continued which would allow making conclusions whether the administrative vice-rector at the university should take on the strategic management function of internal communication.
\end{abstract}

Keywords: higher education institution, internal communication, strategic management, strategy.

\section{Introduction}

The researchers identified in the study, including Gupta and Senger, have identified internal communication as the central activity in an organization, 
Zaumane, 2021. Strategic Internal Communication: Analysis of the Practice of Regional Higer Educational Institutions of Latvia

irrespective of whether it is an educational, non-governmental, non-profit, or forprofit organization (Gupta \& Senger, 2020). However, studies analysing internal communication in higher education institutions (HEIs) reflect a trend that this function is underdeveloped due to the complex and bureaucratic nature of HEIs (Hollingsworth 2017; Tahir, 2010; Tomaselli, 2018, cited in Delport, 2020). This, in turn, has a significant impact on the achievement of the strategic goals of universities, which means losing in competition with other higher education institutions where the strategic goal of the organization is closely linked to the implementation of HEI internal communication management. In turn, this could threaten the sustainability of higher education institutions.

The aim of this study is to analyse the internal communication management practices of four regional universities, as well as to find out the knowledge of the university management level representatives about strategically managed internal communication. Within the framework of the research, two research questions have been raised:

Q1: Who currently manages the internal communication function of HEI?

Q2: To what extent can HEI's internal communication management practices be considered strategic?

The study analyses international literature on the strategic management of organizations and the strategic management of internal communication. In order to achieve the aim of the research, the author uses questionnaires and semistructured interviews with respondents indicating that their university has developed an internal communication strategy. Within the framework of the research, it is planned to provide recommendations for further research.

\section{Literature Review}

Strategic internal communication derives from the theories of strategic management and communication management. Therefore, the connection between these concepts will be described, and the essence of the strategic management of internal communication will be explained.

The strategic management of internal communication derives from the basic concept of strategic management, providing for strategic planning, strategic implementation and strategic control (Mišankova \& Kočišova, 2013). And the research conducted in companies shows that the strategic implementation is rated the lowest (Mišankova \& Kočišova 2013). Mišankova and Kočišova also refer to Sadler's definition that strategy is a complex process of defining activities that helps companies achieve goals and offers medium- and long-term tasks before providing operational solutions. Moreover, Gurowitz adds that there is a direct link between strategy implementation, leadership and communication, emphasizing that they are inseparable (Gurowitz, 2012, cited in Mišankova \& 
Kočišova, 2013). Other researchers Andreas Rasche, David Seidl, referring to Lahman's theory that social systems consist of communication, state that strategic management should be defined and conceptualized as communication (Rasche \& Seidl, 2016). Thus, researchers in management sciences indirectly highlight the important role of internal communication in the strategic management process.

However, the strategic management of internal communication also derives from the overall concept of communication strategic management. Goodman is confident that the main task of strategic communication is to communicate efficiently with all stakeholders - both internal and external (Goodman, 2000), while Argenti adds the necessity to support the development of positive attitude among employees (Argenti, 2000 cited by Mohamad, Bakar, Halim, \& Ismail, 2014). Meanwhile, already in 1995 Van Riel argued that the most important strategic mission of corporate communication is to ensure the competitive advantage of the company (Goodman, 2000).

Scholes, taking a stakeholder perspective, defines internal communication as follows: "Professional management of interactions between all those with an interest or 'a stake' in a particular organisation" (Scholes, 1997 cited by Welch \& Jackson, 2007). This definition suggests a strategic approach and focuses on participants or stakeholders in internal communication. Rickard Andersson also emphasizes in his study that employees are key players in strategic internal communication who may or may not take responsibility for the communication process (Andersson, 2019). The definition includes a significant turn in the development of the research of internal communication - as Scholes marks internal communications as a professional process, it is a signal about the role of internal communication in the organization's strategic management. Thus, Welch and Jackson, combining what different authors have said, create their own definition for strategic internal communication: "strategic management of interactions and relationships between stakeholders within organisations across a number of interrelated dimensions” (Welch \& Jackson, 2007).

Besides, communication can be called strategic internal communication when it is managed with a goal to connect the internal stakeholders with the organization's strategic intention. When this happens, the strategic internal communication can result in improvement of the organization's performance, characterized by the following: increased employee engagement, sense of belonging to the organization, improvement of corporate reputation and prestige (Dolphin, 2005; Meyer \& De Wet, 2007 cited by Hume \& Leonard, 2014). David Cowan also points to connecting employees to the strategic purpose as one of the important end results of good internal communication (Cowan, 2017).

According to James E. Grunig, Dozier and Verčič strategic communication has traditionally been viewed as an organizational support function (Grunig, Grunig, \& Dozier, 2002; Verčič \& Grunig, 2000 cited by Falkheimer et al., 2016), 
Zaumane, 2021. Strategic Internal Communication: Analysis of the Practice of Regional Higer Educational Institutions of Latvia

however, considering the growing focus on intangible resources, communication has become relevant to the organization's management (Falkheimer et al., 2016). However, research and practice show that communication professionals are often not involved in the decision-making process. Moreover, Grimshaw and Mike conclude that one of the significant reasons why companies do not have an efficient strategic internal communication function is that there is no understanding of what the strategic internal communication is (Grimshaw \& Mike, 2008 cited by Hume \& Leonard, 2014). Consequently, the management also underestimates the important role of communication in achieving goals and increasing competitiveness. However, the study by Emanuele Invernizi, Silvija Biragi, Stefanija Romenti concludes that internal communication can provide strategic support at three levels: (1) to form a strong link with the organizational context, developing a two-way approach to communication in order to get closer to employees; (2) through a participatory approach to the management of the organization, internal communication expands the organization's ability to engage employees and make them work like entrepreneurs; (3) well-organized internal communication helps managers become effective managers (Invernizi, Biragi, \& Romenti, 2012). Paulo Henrique, Leal Soares, Rozalia Del Daugo emphasize the importance of internal communication planning: "As an organizational process, it is important that the communication with employees is conducted with the clarity of purpose and within a management framework..." (Henrique, Soares, \& Daugo, 2017).

Summarizing the research of all the authors, the main strategic principles of internal communication have been identified and summarized within the framework of this article:

- $\quad$ Presence of the function implementer in the management team;

- Scanning and listening to the internal environment of the organization;

- Targeted communication of the leader about the organization's strategy and its implementation;

- Link of internal communication with the organization's operational strategy and goals;

- $\quad$ Employees as important stakeholders;

- Employee involvement and dialogue in the decision-making process;

- Internal communication planning;

- Evaluation of internal communication activities.

The practical part of this study has been constructed based on these eight principles of strategic internal communication, which allows evaluating the internal communication management practice of regional universities in Latvia. 


\section{Methodology}

Within the framework of the practical part of the research, the strategic internal communication management practice in four regional higher education institutions of Latvia was studied, based on the eight fundamental principles of internal communication management summarized in the literature review. According to two criteria, HEI was selected: (1) organization must be state funded and must be located in one of the four regions of Latvia. The research was implemented in two stages: (1) a questionnaire with closed-ended questions was developed and distributed electronically to the management representatives and communication professionals of six regional HEIs in Latvia; (2) in the second stage, semi-structured telephone interviews were held with the communication representatives of the universities where the study participants had indicated that the HEI had developed an internal communication strategy. The aim of the second stage was to clarify the aspects of the strategic internal communication management from the perspective of the communication manager.

The questionnaire developed within the first stage was based on eight theoretical fundamental principles of the strategic management of internal communication. Nine closed-ended questions were created in two conceptual frameworks: (1) the delegation of the internal communication function within HEI, and (2) the strategic management of internal communication.

The questionnaire was filled in by 12 representatives from four out of six regional HEIs of Latvia, representing all the regions of the country - Vidzeme, Kurzeme, Zemgale and Latgale. Various management representatives participated in the study: a rector; academic vice-rectors; a vice-rector for research; directors of institutes; a dean of a faculty; the head of the Circular Economics Centre; communication management representatives. Given that the topic of the research is related to the internal processes of the organization, the disclosure of which may endanger the competitiveness and reputation of $\mathrm{HEI}$, the represented higher education institutions are described using the codes HEI A; HEI B; HEI C; HEI $\mathrm{D}$, thus ensuring the confidentiality of the study participants.

As there are differences in the design of the structure in the higher education institutions, as well as significant differences in the number of employees, the higher education institutions cannot be compared with each other within the study, but the answers will be analysed separately.

The survey data were analysed both using descriptive statistics by summing up all the answers to the questions about the delegation of the internal communication function, and applying the methodology of qualitative content analysis by investigating the internal communication management practice. The answers provided within the analysis were grouped according to two initially set parameters: the delegation of internal communication management and the 
Zaumane, 2021. Strategic Internal Communication: Analysis of the Practice of Regional Higer Educational Institutions of Latvia

strategic management of internal communication in the analysis of the various university practices. Also, the attitudes and understanding of the strategic internal communication management among different study participants within one HEI were compared.

Within the study, there are recognized limitations of the method. Study gives understanding about each case, and let's analyse trends, but the used methods does not allow a generalization of the data. Consequently, the results can only be extended to regional universities of Latvia.

\section{Research Results}

The aim of the study was to answer the following research questions: Who currently manages the internal communication function of HEI? To what extent can HEI's internal communication management practice be considered strategic? Therefore, the results are described in two parts: analysing the delegation of internal communication management and the compliance of internal communication management with the strategic fundamental principles.

\section{Delegation of internal communication management}

The results of the research show that regional universities have different views on internal communication management. Analysing the delegation of internal communication management and its presence at the management level, 11 out of 12 study participants have indicated that currently internal communication at HEI is managed by the communication manager and his/ her department alone or together with a marketing or human resources specialist. However, it was concluded that in one of the HEIs this function was not delegated to anyone (See Table 1).

In order to analyse whether the communication manager can be considered as a representative of the management group, the answers provided by the research participants about the subordination of structural units and specialists were also analysed. It should be noted that in one of the four HEIs the communication manager is directly subordinate to the rector. In the other three HEIs, these specialists are subordinate to the administrative vice-rector or the director at the level of a vice-rector. This in turn indicates the operational rather than the strategic role of this function. And it should be noted that in all universities, regardless of the subordination of the communication manager, the scanning and researching the organization's internal environment is more often the function of the human resources manager, although in one case the human resources specialist indicated during the phone interview that he/she performs this task when instructions come from the management and not as a self-initiated 
process. In the particular case, the human resources manager also thinks that the management of internal communication does not fall within his/her job responsibilities. In turn, evaluating the answers about the delegation of internal communication management in those universities where this function is delegated to more than one employee, there is room for additional research on which of all the recipients of the delegation plays a leading role in the implementation of the function.

Table 1 Current Delegation of Internal Communication Management in HEI

\begin{tabular}{|l|c|}
\hline Delegation of internal communication management & $\begin{array}{c}\text { Number of research } \\
\text { participants' answers }\end{array}$ \\
\hline Communication manager/ specialist and his/her structural unit & 5 \\
\hline Internal communication manager/ specialist & 1 \\
\hline Marketing department as a whole & 2 \\
\hline $\begin{array}{l}\text { Shared responsibility between communication, marketing and } \\
\text { human resources managers/ specialists }\end{array}$ & 3 \\
\hline Nobody & 1 \\
\hline
\end{tabular}

Source: Author's research data.

$n=12$

In addition, to understand the attitude and position of university management representatives and implementers of internal communication about the ideal version of the management of this function, the question was asked on who should manage internal communication in the organization. Five of all HEI representatives believe that internal communication should be managed by the communication manager, while the remaining responses were divided between marketing, human resources managers, the clerk and the administrative vicerector (See Table 2). These responses on the desirable situation are only partially in line with the existing delegation in the higher education institutions, which means that a discussion would be required in university management teams about the design, delegation and objectives of this function.

The research participants from HEI D have indicated that the function of internal communication management is delegated to both human resources, communication and marketing specialists and vice-rectors. There was a discord among HEI D representatives over who should manage internal communication. Of the three research participants, each had their own opinion - one thought that this function should be led by the marketing manager, the other - by the clerk or the human resources specialist, and the third - by the administrative vice-rector. This ambiguity indicates a varied understanding of the role of internal communication management in an organization. 
Zaumane, 2021. Strategic Internal Communication: Analysis of the Practice of Regional Higer Educational Institutions of Latvia

Table 2 Opinions of Research Participants on Who Should Manage (plan, implement, evaluate) Internal Communication in the University

\begin{tabular}{|l|c|}
\hline Job title (who should manage internal communication) & $\begin{array}{c}\text { Number of research } \\
\text { participants' answers }\end{array}$ \\
\hline Marketing manager & 2 \\
\hline Human resources manager/ specialist & 1 \\
\hline Communication manager & 5 \\
\hline Administrative vice-rector & 2 \\
\hline Clerk & 1 \\
\hline $\begin{array}{l}\text { Shared responsibility between communication and human } \\
\text { resources managers }\end{array}$ & 1 \\
\hline
\end{tabular}

Source: Author's research data.

$n=12$

HEI C was represented by only one participant who is closely involved in the management of the internal communication function. He/she pointed out that currently the rector had delegated the management of internal communication to both the communication manager/ specialist and the Human Resources Management unit as a whole, but, answering the question on who should manage internal communication at the university, the participant indicated that it should be the human resources specialist.

HEI B was represented by three management level employees. Two of the participants gave an answer "difficult to say" to the question whether the rector had clearly delegated the management of internal communication to a particular colleague. When answering the question about the current delegation of the function, one of the participants indicated that the rector had not delegated the management of internal communication to anyone, but two indicated that this function was managed by the communication manager and his/ her structural unit. Two of the participants thought that internal communication should be managed by the communication manager, but the third participant pointed to the human resources director at the level of vice-rector as the possible responsible employee.

HEI A was represented by five management level employees. There was discord among them as to who had been currently delegated to manage the internal communication function. Three of the participants considered that it was the communication manager and his/ her unit, one - that it was the internal communication specialist who was directly subordinate to the rector, another that the delegation was divided between the communication and human resources management units. There was also disagreement about who should manage this function. Three participants considered that internal communication should be managed by the communication manager, one - by the administrative vice-rector, 
and another one - that it could be a shared responsibility among communication, human resources managers and the student club.

\section{Compliance of internal communication management with the strategic principles}

Three of the questions of the survey allowed analysing the attitude and knowledge of university management representatives about strategically managed internal communication, and whether internal communication management at HEI can be considered strategic. The study participants were asked to rate statements about strategically driven internal communication within their HEI on a scale from 1 to 4 (strongly disagree; somewhat disagree; somewhat agree; strongly agree). The statements included both the participation of the implementer of the internal communication function in the management meetings and the planning, implementation, and evaluation aspects of the internal communication.

The study reveals that the attitude and knowledge of HEI management representatives about the strategic internal communication is at a high level, however, none of the four universities fully exploits the strategic potential of internal communication. For example, $75 \%$ of the survey participants when asked to describe the concept of "strategically managed internal communication" indicated the answer "strongly agree" with the statement "the employee responsible for internal communication management participates in defining the strategy and taking important decisions", but when evaluating the real situation in the organization, only $40 \%$ indicated the answer "strongly agree".

Based on the evaluation of the research participants according to the scale, the author of the research summarized the answers provided by creating a table showing the strategic internal communication manifestations according to the eight theoretical fundamental principles in each higher education institution (see Table 3).

The author concludes that only in two of the four HEI the research participants were of the same opinion that the implementer of the internal communication function participates in management meetings and is involved in the organization's strategic planning process. Only one of the four universities fully performs the scanning and regular listening function. In another university, the study participants indicated that this function was not performed at all, but two other institutions - that it was performed partially. Analysing the question on the leader's communication on the strategic goals and positioning of the university, it can be concluded that in one of the four universities the study participants unanimously answered that the rector purposefully communicates the organization's strategy and goals, while the opinions of the representatives of the three other universities differed. In one case, the respondents indicated that they 
Zaumane, 2021. Strategic Internal Communication: Analysis of the Practice of Regional Higer Educational Institutions of Latvia

completely disagreed with the statement that the leader purposefully communicates the strategic purpose, while in another case the respondents at higher-level positions indicated that they somewhat communicated the strategy, but the participant at a lower-level position disagreed completely with this statement, thus it is not possible to unequivocally state the existence of this practice.

It has also been observed in the study that none of the universities has a clear indication of the existence of an internal communication goal and strategy. In two of the four higher education institutions, the research participants indicated that the university had developed an internal communication strategy, but when making clarifications during the telephone interviews, the researcher concluded that internal communication activities were mainly implemented at the operational level, referring to this function as part of the unit's work regulations. However, neither internal communication goals, nor the strategy were defined.

\section{Table 3 Evaluation of Internal Communication Management at Higher Education Institutions According to Eight Theoretical Fundamental Principles (corresponds / partially corresponds / does not correspond with the principle)}

\begin{tabular}{|c|c|c|c|c|}
\hline $\begin{array}{l}\text { Theoretic principles of } \\
\text { strategic internal } \\
\text { communication }\end{array}$ & HEI A & HEI B & HEI C & HEI D \\
\hline $\begin{array}{l}\text { Presence of the function } \\
\text { implementer in the } \\
\text { management team }\end{array}$ & Corresponds & $\begin{array}{c}\text { Partially } \\
\text { corresponds }\end{array}$ & $\begin{array}{c}\text { Partially } \\
\text { corresponds }\end{array}$ & $\begin{array}{c}\text { Partially } \\
\text { corresponds }\end{array}$ \\
\hline $\begin{array}{l}\text { Scanning and listening to the } \\
\text { internal environment of the } \\
\text { organization }\end{array}$ & Corresponds & $\begin{array}{c}\text { Does not } \\
\text { correspond }\end{array}$ & $\begin{array}{c}\text { Partially } \\
\text { corresponds }\end{array}$ & $\begin{array}{c}\text { Partially } \\
\text { corresponds }\end{array}$ \\
\hline $\begin{array}{l}\text { Targeted communication of the } \\
\text { leader about the organization's } \\
\text { strategy and its implementation }\end{array}$ & Corresponds & $\begin{array}{l}\text { Does not } \\
\text { correspond }\end{array}$ & $\begin{array}{l}\text { Partially } \\
\text { corresponds }\end{array}$ & $\begin{array}{l}\text { Partially } \\
\text { corresponds }\end{array}$ \\
\hline $\begin{array}{l}\text { Link of internal } \\
\text { communication with the } \\
\text { organization's operational } \\
\text { strategy and goals; }\end{array}$ & $\begin{array}{c}\text { Partially } \\
\text { corresponds }\end{array}$ & $\begin{array}{c}\text { Partially } \\
\text { corresponds }\end{array}$ & Corresponds & $\begin{array}{c}\text { Partially } \\
\text { corresponds }\end{array}$ \\
\hline $\begin{array}{l}\text { Employees as important } \\
\text { stakeholders }\end{array}$ & Corresponds & $\begin{array}{c}\text { Partially } \\
\text { corresponds }\end{array}$ & $\begin{array}{c}\text { Partially } \\
\text { corresponds }\end{array}$ & $\begin{array}{c}\text { Partially } \\
\text { corresponds }\end{array}$ \\
\hline $\begin{array}{l}\text { Employee involvement and } \\
\text { dialogue in the decision- } \\
\text { making process }\end{array}$ & Corresponds & $\begin{array}{c}\text { Partially } \\
\text { corresponds }\end{array}$ & Corresponds & $\begin{array}{c}\text { Partially } \\
\text { corresponds }\end{array}$ \\
\hline $\begin{array}{l}\text { Internal communication } \\
\text { planning }\end{array}$ & $\begin{array}{l}\text { Does not } \\
\text { correspond }\end{array}$ & $\begin{array}{c}\text { Does not } \\
\text { correspond }\end{array}$ & $\begin{array}{l}\text { Does not } \\
\text { correspond }\end{array}$ & $\begin{array}{c}\text { Partially } \\
\text { corresponds }\end{array}$ \\
\hline $\begin{array}{l}\text { Evaluation of internal } \\
\text { communication activities }\end{array}$ & $\begin{array}{c}\text { Partially } \\
\text { corresponds }\end{array}$ & $\begin{array}{c}\text { Does not } \\
\text { correspond }\end{array}$ & $\begin{array}{l}\text { Does not } \\
\text { correspond }\end{array}$ & $\begin{array}{c}\text { Does not } \\
\text { correspond }\end{array}$ \\
\hline
\end{tabular}

Source: Summary of the author's research results. 
As the research does not provide an unambiguous answer about the practice of defining the strategy of internal communication in regional universities, the author evaluates the analysed practice as partly in line with the strategic fundamental principles.

In the evaluation of the internal communication practice, the participants of the study more often indicate that they somewhat disagree with the statement that the employees of the university would be regularly invited to evaluate the internal communication activities or that the internal communication plan would be regularly reviewed. One of the eight fundamental principles of the strategic internal communication is employees as stakeholders and the promotion of dialogue between the management and employees. In three of the four HEIs, participants either somewhat disagreed or somewhat agreed with the statement that employees are important stakeholders that need to be involved in the decision-making process. However, when asked whether the management purposefully promotes the dialogue between employees and management representatives, two university representatives in their self-assessment of internal communication indicated that the dialogue was facilitated, while there was no consensus in other two universities, the opinion ranged from "strongly disagree" to "somewhat agree".

\section{Conclusions and Discussion}

The results of the research show that in Latvian regional HEIs there may exist very different views within one organization on both the delegation of internal communication management and the strategic management of internal communication.

At present, it can be observed that the practice of delegating and managing the internal communication function in higher education institutions is implemented according to the same principles as it is implemented by business organizations. In most cases, this function is performed by communication, marketing or human resources managers and specialists. Therefore, it can be concluded that both in HEI and business this function is performed at the operational rather than the strategic level. And since there are universities where the delegation is unclear, there is a possibility that internal communication is implemented in a fragmented way, without a single specific manager who leads and directs the process with a specific goal. The strategic implementation of internal communication is also threatened, as the main goal of most university communication, public relations and marketing departments is to "sell" the university as a great place to study, which means that the priority goals of these departments are related to external stakeholder communication and relations, leaving internal communication as a secondary task. Therefore, in future research 
Zaumane, 2021. Strategic Internal Communication: Analysis of the Practice of Regional Higer Educational Institutions of Latvia

it would be worthwhile to explore who should lead the internal communication in the university management team, proposing a hypothesis that the administrative vice-rector who is part of the management team and who is responsible for the communication units would be one of the solutions to make internal communication management a management-level function with a specific goal and strategic positioning. And the second suggestion for future research would be to analyse the connection between the extent of strategic internal communication management practice and the success of implementing the organization's strategy.

\section{References}

Andersson, R. (2019). Employee Communication Responsibility: Its Antecedents and Implications for Strategic Communication Management. International Journal of Strategic Communication, 13(1), 60-75.

Cowan, D. (2017). Strategic Internal Communication. How to build employee engagement and performance. Second Edition. London: Cogan Page, p.26.

Delport, M. (2020). Lost in Communication in Higher Education. Communication, 46(3), 106126.

Falkheimer, J., Heide, M., Nothhaft, H., Sara von Platen, Simonsson, Ch., \& Andersson, R. (2017). Is Strategic Communication too important to be left to Communication Professionals?: Managers' and coworkers' attitudes towards strategic communication and communication professionals. Public Relations Review, 43(1), 91-101.

Goodman, M. B. (2000). Corporate communication: the American picture. Corporate Communications: An International Journal, 5(2), 69-74.

Gupta, K. P., \& Sengar, R. (2020). Organisational communication in higher educational institutions: scale development and validation. Int. J. Education Economics and Development, Vol. 11, No.1.

Henrique, P., Soares, L., \& Del Gaudo, R. (2018). Megaphones out, Smartphones In. Practices, challenges, and dillemmas of communication with employees. San Paulo: Aberje, p.33.

Hume, J., \& Leonard, A. (2013). Exploring the strategic potential of internal communication in international non-governmental organisations. Public Relations Review, 40(2), 294-304.

Invernizzi, E., Biraghi, S., \& Romenti, S. (2016). Entrepreneurial communication and the strategic role of internal communication. Retrieved from https://docplayer.net/ 9592459-Entrepreneurial-communication-and-the-strategic-role-of-internalcommunication.html

Mišankováa, M., \& Kočišováa, K. (2014). Strategic implementation as a part of strategic management. Contemporary Issues in Business, Management and Education conference. Procedia - Social and Behavioral Sciences, 110.

Mohamad, B., Bakar, H. A., Halim, H., \& Ismail, A. R. (2014). Corporate Communication Management (CCM) and Organisational Performance: A Review of the Current Literature, Conceptual Model and Research Propositions. Procedia - Social and Behavioral Sciences, 155, 115-122.

Rasche, A., \& Seidl, D. (2016). A Luhmannian Perspective on Strategy: Strategy as Paradox and Meta-Communication. Critical Perspectives on Strategy: Strategy as Paradox and Meta-Communication. Retrieved from https://ssrn.com/abstract=2777483 
SOCIETY. INTEGRATION. EDUCATION Proceedings of the International Scientific Conference. Volume VI, May $28^{\text {th }}-29^{\text {th }}$, 2021. 551-563

Welch, M., \& Jackson, P. R. (2007). Rethinking internal communication: a stakeholder approach. Corporate Communications: An International Journal, 12(2), 177-198. 
